\title{
Öğretmen Adaylarının Dijital Okuryazarlık Öz-yeterlilik Becerilerinin Farkı Değişkenler Açısından İncelenmesi
}

\author{
An Investigation of Digital Literacy Self-efficacy Skills of Pre-Service Teachers In \\ Terms of Different Variables
}

\author{
Prof. Dr. Gürbüz OCAK ${ }^{1}$, Doktora Öğrencisi Gülçin KARAKUŞ ${ }^{2}$
}

\begin{abstract}
Özet
Bu çalışmanın amacı öğretmen adaylarının dijital okur-yazarlık öz-yeterlilik becerilerini cinsiyet, öğrenim görmekte oldukları bölüm, anne ve baba eğitim durumu, mezun oldukları okul türü, bilgisayar erişim olanakları açısından incelemektir. Çalışmada Ocak ve Karakuş (2018) tarafindan geliştirilen "Öğretmen Adaylarının Dijital Okuryazarlık Öz-yeterliliği Ölçeği (ÖADOÖÖ)" olarak adlandırılan Cronbach-Alpha iç tutarlık sayısı 0. 961 olan likert tipi ölçek kullanılmıştır. Çalışmanın örneklemini Ege Bölgesinde bir üniversitede öğrenim gören 284 öğrenci oluşturmaktadır. Çalışmanın verileri 2018-2019 eğitim öğretim yılı güz döneminde elde edilmiştir. Çalışma sonucunda öğretmen adaylarının dijital okuryazarlık öz-yeterliklerinin yüksek olduğu, cinsiyetin bir alt boyutta etkili olduğu, anne baba eğitim durumunun etkili olmadığı, bilgisayar öğretmenliği bölümünün dijital okuryazarlık öz-yeterlik düzeyinin yüksek olduğu ve meslek liselerinden mezun olan öğretmen adaylarının dijital okuryazarlık öz-yeterlik düzeylerinin düşük olduğu sonucuna ulaşılmıştır.
\end{abstract}

Anahtar Kelimeler: Öğretmen adayları, dijital okuryazarlık, öz-yeterlik

Makale Türü: Araştırma makalesi

\begin{abstract}
The aim of this study is to examine the digital literacy self-efficacy skills of pre-service teachers in terms of gender, the department they study, the educational status of their parents, the type of school they graduate, and having computer or not. In this study, Digital Literacy Self-Efficacy Scale of Pre-service Teachers (ÖADOÖÖ) was used. Scale was developed by the Ocak and Karakuş (2018). The scale's Cronbach-Alpha co-efficiency was 0.961 . The sample of the study consists of 284 students studying at a university in the Aegean Region. The data of the study were obtained in the fall semester of 2018-2019 academic year. According to the results it is concluded that the pre-service teachers have high levels of digital literacy self-efficacy, gender is effective in one sub-dimension, pre-service teachers' parents' education status is not effective, the level of digital literacy self-efficacy of the computer teaching department is high and that the digital literacy self-efficacy levels of vocational high schools are low.
\end{abstract}

Keywords: Preservice teachers, digital literacy, self efficacy

Paper Type: Research paper

\footnotetext{
${ }^{1}$ Afyon Kocatepe Üniversitesi, Eğitim Fakültesi, gocak@aku.edu.tr , Orcid ID: https://orcid.org/ 0000-0001-8568-0364 ${ }^{2}$ Sivas Mustafa Kemal Atatürk Mesleki Teknik Lisesi, Sivas, karakusgulcin@gmail.com, Orcid ID: https://orcid.org/ 00000002-0587-4079
} 


\section{Giriş}

Eğitim ortamı içinde bulunduğumuz çağın hızlı gelişsimi ve değişiminden etkilenmekte öğrenci, öğretmen ve öğretim ortamını da bu değişime ayak uydurmaya yönlendirmektedir. Özellikle bu uyumun sağlanmasında öğretmenin temel görevi bu değişim ve gelişimi takip etmek ve kendisini bu doğrultuda eğitmek, öğrencilere bu yönde rehber olmaktır. Hızla ilerleyen teknolojik gelişmelerden etkilenen öğrenme ortamı dijital kaynaklar ile daha geniş kapsamlı bilgi ağını öğrenci için kullanılabilir bir yapıya dönüştürmektedir. Dijital bir ortamda eğitim alan öğrencilerin dijital okuryazarlık bilincine de sahip olmaları bu hıza uyum sağlamaları için gereklidir (Murray, 2013; Techataweewan \& Prasertsin, 2017). Nitekim günümüzde öğrencilerin dijital araçları kullanımı oldukça erken yaşlara kadar inmiştir. Ancak elbette ki öğrencilerin bu teknolojileri verimli olacak şekilde bilinçli kullanabilmeleri ve herhangi bir olumsuzlukla karşılaşıldığında büyüklerinden yardım alabilmeleri önemlidir (Acar, 2015).

Eğitim teknolojilerinde meydana gelen değişikliler temelde sınırlı sayıda olan materyal ve kaynaklarda çeşitliliğe ve öğrenim süresinin kısalmasına aynı zamanda da her yerde öğrenim alınmasına imkân sağlamaktadır ( Lewis \& Alirezabeigi, 2018). Örneğin gün geçtikçe yaygınlaşan akıllı sınıflar, akıllı uygulamalar, öğrencinin okula ve eğitim öğretime yönelik tutumunu olumlu yönde etkilemektedir.

Dijital okuryazarlık yirmi birinci yüzyılın en önemli becerilerinden biridir. Sınıf ortamını dijital kaynaklarla daha verimli kullanabilmesi açısından öğretmenlerin de dijital okuryazarlık becerisine sahip olmaları önemlidir. Dijital okuryazarlık dijital alet ve teknolojilerin kullanılmasının ötesinde bir kavramdır. Dijital okuryazarlık, dijital bir ortamda gereken uygulamaları sergileyebilecek bilgi, beceri ve tutuma sahip olmaktır (Ferrari, 2012; Porat, Blau \& Barak, 2018).

Dijital okuryazar bir birey, yaratıcı, yenilikçi, işbirliği yapabilen, iletişim kurabilen, eleştirel düşünen, problem çözebilen, karar verme becerisi gelişmiş, teknolojik kavramların ne demek olduğunu bilen ve bu doğrultuda bu kavramları kullanabilen, dijital bir vatandaş olarak gerekenleri yapabilen bireydir ( The International Society For Technology in Education, 2007). Değişik ve farklı medya ve teknolojilere uyum sağlayan, donanım, yazılım, internet, cep telefonu, dijital cihazlar ve Web 2.0 gibi araçları etkin olarak kullanan bireydir (Tyger, 2011).

Dijital okuryazarlık bilginin kaynağı ve bu bilginin uygulanması arasında bir köprü görevindedir. Ancak elbette dijital okuryazarlığın olumsuz etkileri de söz konusu olabilir. Teknoloji bağımlılığı, bilginin tek bir merkezdeki hâkimiyetinin azalması, kontrolün dağılması, okullaşma kavramını zedelenmesi eğitim ortamını etkileyebilecek olumsuzluklar arasında gösterilebilir ( Mc Dougall, Readman \& Wilkinson, 2018). Ayrıca dijital okuryazar bir bireyin uyması gereken bazı etik kuralların da farkında olması gerekmektedir. Dijital ortamda örneğin sanal ortamda sosyal medyanın doğru ve kontrollü kullanılması, sanal zorbalığa yönelik davranışlardan kaçınılması, kişinin özel haklarına saygı duyulması gibi unsurlar hakkında tüm kullanıcıların bilgi sahibi olmaları ve bu doğrultuda hareket etmeleri gerekmektedir (Atif \& Chou, 2018).

Geleneksel eğitim ortamından, geleneksel defter kitap, basılı yayın materyallerinden uzaklaşılması, dijital okuryazarlık beceri düzeyinin arttırılması, sınıf içinde bu uygulamaların yapılması, eğitim ve öğretim alanı olarak sınıfı ve dersi öğrenci için daha ilgi çekici bir 
yapıya dönüştürecektir ( Starr, 2012). Temelde dijital okuryazarlık tüm eğitim kademelerinde yer almalı ve etkin olarak kullanılmalıdır. Bu sayede dijital okuryazarlık becerisi gelişen öğrenciler ilerleyen yıllarda iş ve özel hayatlarında bu becerinin olumlu etkilerini görecek ve daha başarılı olacaklardır ( Lefler, 2015).

Sınıf içinde ve ilerleyen yıllarda öğrenciye sağladığı pek çok olumlu etki bağlamında dijital okuryazarlık öğretmen eğitim programlarında yer alabilir. Böylece öğretmen adaylarının dijital okuryazarlık becerileri gelişebilir. (Güneş ve Bahçivan, 2018). Lisans öğrencileri sadece bilgi edinmekle kalmamalı aynı zamanda çağın gerektirdiği şekilde kendilerini dijital okuryazar bir birey olarak hazırlamalıdır (Techataweewan \& Prasertsin, 2017). Bu sayede, öğretmen öğretimini geliştirebilir, teknolojik materyaller ile ilgili bilgi sahibi olabilir, sınıf içinde teknolojiyi kullanabilir ve hem kendisinin hem de ögrencilerin teknolojiye karşı olumlu bir tutuma sahip olmalarına destek olabilir.

Sınıf ortamında ve bireysel gelişimde tüm bu olumlu etkileri dikkate alındığında alanyazında (Khalid, Slættalío, Parveen \& Hossain, 2015; Svensson \& Baelo, 2015; Campbell, 2016; Rambousek, Štípek, \& Vaňková ,2016) ;Gasaymeh, Al-Tawel, AlMoghrabi \& Al-;Ghonmein, 2017) öğretmen adaylarını dijital okuryazar olmaları önemli olarak görülmektedir. İçinde bulunduğumuz çağda $Z$ kuşağına eğitim verecek olan öğretmen adaylarının bu kuşağa eğitim verecek düzeyde dijital okuryazar olmaları gerekir. $\mathrm{Bu}$ bağlamda bu çalışmada öğretmen adaylarının dijital okuryazarlık beceri düzeyleri ve dijital okuryazarlıklarının cinsiyet, öğrenim görmekte oldukları bölüm, anne ve baba eğitim durumu, internet ve bilgisayar erişim olanakları, mezun oldukları okul türü açısından incelenmesi amaçlanmaktadır.

\section{Problem Cümlesi}

Öğretmen adaylarının dijital okuryazarlık beceri düzeyleri nasıldır? Bu düzeyler arasında bazı değişkenler açısından anlamlı farklılık var mıdır?

\subsection{Alt Problemler}

1. Öğretmen adaylarının dijital okuryazarlık beceri düzeyleri nasıldır?

2. Cinsiyet dijital okuryazarlık öz-yeterlikleri üzerinde anlamlı bir farklılık oluşturmakta mıdır?

3. Öğrenim görmekte oldukları bölüm öğretmen adaylarının dijital okuryazarlık özyeterlikleri üzerinde anlamlı bir farkl1lık oluşturmakta mıdır?

4. Öğretmen adaylarının anne eğitim durumları dijital okuryazarlık öz-yeterlikleri üzerinde anlamlı bir farklılık oluşturmakta mıdır?

5. Öğretmen adaylarının baba eğitim durumları dijital okuryazarlık öz-yeterlikleri üzerinde anlamlı bir farklılık oluşturmakta mıdır?

6. Öğretmen adaylarının internete erişim imkânları dijital okuryazarlık öz-yeterlikleri üzerinde anlamlı bir farklılık oluşturmakta mıdır? 
7. Öğretmen adaylarının bilgisayar erişim imkânları dijital okuryazarlık özyeterlikleri üzerinde anlamlı bir farklılık oluşturmakta mıdır?

8. Öğretmen adaylarının mezun oldukları okul türü dijital okuryazarlık özyeterlikleri üzerinde anlamlı bir farklılık oluşturmakta mıdır?

\section{Yöntem}

Çalışma genel tarama modelinde yürütülmüştür. Tarama modeli genelleme yapabilmek amacıyla geniş çapta veri toplanan (Cohen, Manion \& Morrison, 2007), belirli bir konu ya da konular hakkında soru sorulan ve alınan cevapların betimlendiği yöntemdir ( Jackson, 2015). Çalışmanın yürütüldüğü üniversite ülkemizdeki üniversitelerin büyük çoğunluğunun profilini yansıtacak şekilde orta düzeyde başarılı bir üniversitedir, bu bağlamda bu üniversitedeki öğrencilerden alınacak verilerin geneli yansıtma gücü yüksektir. $\mathrm{Bu}$ nedenle bu çalışmada tarama modeli tercih edilmiştir. Bu çalışmada Ege bölgesinde bir üniversitenin Eğitim Fakültesi son sınıf öğrencilerinin dijital okuryazarlık öz-yeterlikleri üzerinde bazı değişkenlerin bir fark oluşturup oluşturmadığı belirlenmeye çalışılmıştır

\section{1. Örneklem}

Çalışmanın örneklemini ilgili eğitim fakültesinde öğrenim gören 284 öğretmen adayı oluşturmaktadır. Örneklemin son sınıfta öğrenim gören öğretmen adaylarından oluşması amaçlı olarak tercih edilmiştir. Amaçlı örnekleme yönteminde araştırmacının önceden belirlediği bir amaç vardır ve örneklem bu doğrultuda bu amaca uygun olarak seçilir, örnekle taşıması gereken özellikleri kapsamında araştırmada tercih edilir ( Etikan, Musa \& Alkassim , 2016). Öğretmen adaylarının son sınıfta dijital okuryazarlık seviyelerinin daha belirgin olacağı dikkate alınmıştır.

\subsection{Veri Toplama Aracı}

Çalışmada veri toplama aracı olarak Ocak ve Karakuş (2018) tarafından geliştirilen "Öğretmen Adaylarının Dijital Okuryazarlık Öz-yeterliliği Ölçeği (ÖADOÖÖ)” olarak adlandırılan likert tipi ölçek kullanılmıştır. Ölçeğin tüm boyutları için (35 madde) güvenirlik katsayısı 0.961 olarak hesaplanmıştır. Ölçeğin açıkladığı varyans oranları Tablo 1 ' de verilmiştir.

Tablo 1' de görüldüğü gibi, Rotated Companent Matrix (Döndürülmüş Bileşenler Matriksi) 1. faktörde 11 maddenin, 2. faktörde 10 maddenin, 3. faktörde 9, 4. faktörde 5 maddenin bulunduğu tespit edilmiştir. Çalışmada kullanılan ölçeğin geliştirilme sürecinde hesaplanan ölçeğin alt boyutlarına ve tamamına ilişkin güvenilirlik analizleri sonucunda Cronbach Alpha değerlerinin 1. Faktör için .90, 2. Faktör için .88, 3. Faktör için .86, 4. Faktör için .81 ve toplam için .96 olduğu belirlenmiştir. Bu çalışmada ise elde edilen güvenirlik analizi sonuçları ise 1. Faktör için .868 , 2. Faktör için .909, 3. Faktör için .883, 4. Faktör için ise .884 , toplam için ise .835 olarak tespit edilmiştir. 
Tablo 1. Öğretmen adaylarının dijital okur-yazarlık öz-yeterliliği ölçeğinin toplam varyansı açıklanması tablosu

\begin{tabular}{|c|c|c|c|c|c|c|c|c|c|}
\hline & & \multicolumn{2}{|c|}{ Öz Değerler } & \multicolumn{3}{|c|}{$\begin{array}{c}\text { Karesi Alınan Yüklerin Toplam } \\
\text { Çıkarımı }\end{array}$} & \multicolumn{3}{|c|}{$\begin{array}{c}\text { Karesi Alınan Yüklerin Döndürme } \\
\text { Toplamı }\end{array}$} \\
\hline & Toplam & $\%$ Varyans & Birikimli \% & Toplam & $\%$ Varyans & Birikimli \% & Toplam & $\%$ Varyans & Birikimli \% \\
\hline 1 & 13.089 & 37.397 & 37.397 & 13.089 & 37.397 & 37.397 & 6.008 & 17.167 & 17.167 \\
\hline 2 & 2.687 & 7.676 & 45.073 & 2.0687 & 7.676 & 45.073 & 5.249 & 14.997 & 32.164 \\
\hline 3 & 1.653 & 4.723 & 49.796 & 1.653 & 4.723 & 49.796 & 4.425 & 12.614 & 44.778 \\
\hline 4 & 1.181 & 3.373 & 53.169 & 1.181 & 3.373 & 53.169 & 2.937 & 8.390 & 53.169 \\
\hline
\end{tabular}

\subsection{Verilerin Analizi}

Verilerin analizinde, öğrencilerin verdikleri cevapların puanlarını hesaplamak amaciyla ölçekte yer alan maddeler; 4.20-5.00 "Her zaman", , 3.40-4.19“Sıklıkla", 2-60-3.39 "Ara sıra", , 1.80-2.59"Nadiren", 1-1.79 "Asla" aralıkları temel alınarak yorumlanmıştır. Yapılan normallik testi sonuçlarına göre ölçeğin tümü ve her bir alt faktörü için elde edilen verilerin normal dağılım göstermemeleri nedeniyle verilerin çözümlenmesinde, aritmetik ortalama, frekans, yüzde, Mann-Whitney U ve Kruskal Wallis H-Test istatistik işlemleri kullanılmıştır.

\section{Bulgular ve Yorumlar}

Bu bölümde bulgular, araştırmanın alt problemlerine göre sunulmuştur.

\section{1.Öğretmen adaylarının dijital okuryazarlık beceri düzeyleri nasıldır?}

Öğretmen adaylarının dijital okuryazarlıklarının üretim boyutunda frekans, yüzde ve madde ortalamaları dağılımı Tablo 2'de verilmiştir. 
Tablo 2. Ölçeğin birinci boyutu ( üretim ) ile ilgili yüzde, frekans ve madde ortalamaları

\begin{tabular}{|c|c|c|c|c|c|c|c|c|c|}
\hline & Boyutta yer alan maddeler & & 1 & 2 & 3 & 4 & 5 & $\mathbf{X}$ & Sonuç \\
\hline & Dijital ortamda öğrenci düzeyine uygun & $\mathrm{f}$ & 6 & 19 & 52 & 81 & 126 & & \\
\hline & $\begin{array}{l}\text { değerlendirme çalışmaları } \\
\text { hazırlayabilirim. }\end{array}$ & $\%$ & 2.1 & 6.7 & 18.3 & 28.5 & 44.4 & 4.06 & Siklıkla \\
\hline & Dijital ortamda öğrencinin konuyu & f & 4 & 17 & 55 & 86 & 122 & & \\
\hline & $\begin{array}{l}\text { pekiştirmesini sağlayacak uygulamalar } \\
\text { hazırlayabilirim. }\end{array}$ & $\%$ & 1.4 & 6.0 & 19.4 & 30.3 & 43.0 & 4.07 & Siklıkla \\
\hline & Farklı öğrenme stillerine sahip & $\mathrm{f}$ & 6 & 24 & 53 & 91 & 110 & & \\
\hline & $\begin{array}{l}\text { öğrencilere yönelik dijital materyal } \\
\text { hazırlayabilirim. }\end{array}$ & $\%$ & 2.1 & 8.5 & 18.7 & 32.0 & 38.7 & 3.96 & Siklıkla \\
\hline & Dijital ortamda öğrenci ödevlerini & f & 7 & 15 & 55 & 101 & 106 & & \\
\hline & değerlendirebilirim. & $\%$ & 2.5 & 5.3 & 19.4 & 35.6 & 37.3 & 4.00 & Siklıkla \\
\hline & Öğrencinin daha hızlı bilgi & $\mathrm{f}$ & 2 & 12 & 54 & 81 & 135 & & \\
\hline & $\begin{array}{l}\text { paylaşabilmesi için dijital kaynak } \\
\text { kullanabilirim }\end{array}$ & $\%$ & .7 & 4.2 & 19.0 & 28.5 & 47.5 & 4.17 & Siklıkla \\
\hline & Dijital kaynaklarla sınav & $\mathrm{f}$ & 22 & 40 & 64 & 85 & 73 & & \\
\hline & hazırlayabilirim (örneğin kahoot gibi). & $\%$ & 7.7 & 14.1 & 22.5 & 29.9 & 25.7 & 3.51 & Siklikla \\
\hline & Eğitim öğretim amaçlı video & $\mathrm{f}$ & 9 & 13 & 58 & 59 & 145 & & \\
\hline & hazırlayabilirim. & $\%$ & 3.2 & 4.6 & 20.4 & 20.8 & 51.1 & 4.11 & Siklikla \\
\hline & Öğrenme ortamını zenginleştirmek için & $\mathrm{f}$ & 3 & 12 & 37 & 80 & 152 & 428 & Her \\
\hline & dijital kaynak kullanabilirim. & $\%$ & 1.1 & 4.2 & 13.0 & 28.2 & 53.5 & 4.28 & zaman \\
\hline & Ders anlatırken dijital kitapları & $\mathrm{f}$ & 2 & 15 & 49 & 87 & 131 & & S.kl1kla \\
\hline & kullanabilirim (e-kitap, z-kitap vb.) & $\%$ & .7 & 5.3 & 17.3 & 30.6 & 46.1 & 4.16 & Siklikla \\
\hline & Sınıfta yaptığım bir etkinliği paylaşım & f & 3 & 21 & 47 & 70 & 143 & & \\
\hline & $\begin{array}{l}\text { sitelerine yükleyerek öğrenciyi motive } \\
\text { edebilirim. }\end{array}$ & $\%$ & 1.1 & 7.4 & 16.5 & 24.6 & 50.4 & 4.15 & Siklikla \\
\hline & Anlattı̆̆ı̆ dersi dijital ortamda & $\mathrm{f}$ & 5 & 11 & 40 & 78 & 150 & & \\
\hline & 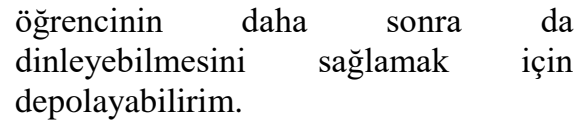 & $\%$ & 1.8 & 3.9 & 14.1 & 27.5 & 52.8 & 4.25 & $\begin{array}{l}\text { Her } \\
\text { zaman }\end{array}$ \\
\hline & Toplam & & & & & & & 4.07 & Siklıkla \\
\hline
\end{tabular}

Tablo 2 incelendiğinde öğretmen adaylarının dijital okuryazarlık öz-yeterlik ölçeğinin üretim alt boyutuna çoğunlukla "Sıklıkla" cevabını verdikleri, sadece "Öğrenme ortamını zenginleştirmek için dijital kaynak kullanabilirim" ve "Anlattı̆̆ım dersi dijital ortamda öğrencinin daha sonra da dinleyebilmesini sağlamak için depolayabilirim" maddelerine "Her zaman" cevabını verdikleri görülmektedir.

Öğretmen adaylarının dijital okuryazarlıklarının kaynak kullanabilme boyutunda frekans, yüzde ve madde ortalamaları dağılımı Tablo 3'de verilmiştir. 
Tablo 3. Ölçeğin ikinci boyutu (kaynak kullanabilme) ile ilgili yüzde, frekans ve madde ortalamalar1

\begin{tabular}{|c|c|c|c|c|c|c|c|c|c|}
\hline & Boyutta yer alan maddeler & & 1 & 2 & 3 & 4 & 5 & $\mathbf{X}$ & Sonuç \\
\hline & Akıllı tahta kullanabilirim. & $\begin{array}{l}\mathrm{F} \\
\%\end{array}$ & $\begin{array}{l}1 \\
4\end{array}$ & $\begin{array}{l}1 \\
4\end{array}$ & $\begin{array}{l}13 \\
46\end{array}$ & 63 & 206 & 4.66 & Her \\
\hline & Eğitim öğretim uygulamalarını cep & $\mathrm{F}$ & 0 & 2 & 10 & 50 & 222 & & \\
\hline & telefonuma yükleyebilirim. & $\%$ & 0 & .7 & 3.5 & 17.6 & 78.2 & 4.73 & zaman \\
\hline & Tablet kullanabilirim. & $\begin{array}{l}\mathrm{F} \\
\%\end{array}$ & $\begin{array}{l}0 \\
0\end{array}$ & $\begin{array}{l}3 \\
1.1\end{array}$ & $\begin{array}{l}16 \\
5.6\end{array}$ & $\begin{array}{l}56 \\
19.7\end{array}$ & $\begin{array}{l}209 \\
73.6\end{array}$ & 4.65 & $\begin{array}{l}\text { Her } \\
\text { zaman }\end{array}$ \\
\hline \multirow{10}{*}{ 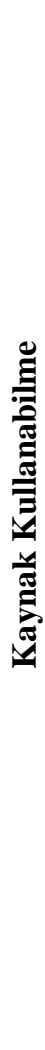 } & $\begin{array}{l}\text { Dijital ortamdaki kaynaklara kolaylıkla } \\
\text { ulaşabilirim. }\end{array}$ & $\begin{array}{l}\mathrm{F} \\
\%\end{array}$ & $\begin{array}{l}1 \\
.4\end{array}$ & $\begin{array}{l}1 \\
.4\end{array}$ & $\begin{array}{l}11 \\
3.9\end{array}$ & $\begin{array}{l}35 \\
12.3\end{array}$ & $\begin{array}{l}236 \\
83.1\end{array}$ & 4.77 & $\begin{array}{l}\text { Her } \\
\text { zaman }\end{array}$ \\
\hline & $\begin{array}{l}\text { Öğrenciler ya da velilerle iletişim } \\
\text { kurabileceğim bir grup } \\
\text { kurabilirim(örneğin whatsann grubu) }\end{array}$ & $\begin{array}{l}\mathrm{F} \\
\%\end{array}$ & 0 & .4 & 7.0 & 24.3 & 68.3 & 4.60 & $\begin{array}{l}\text { Her } \\
\text { zaman }\end{array}$ \\
\hline & $\begin{array}{l}\text { Eğitimi destekleyen web sitelerinden } \\
\text { yararlanabilirim. }\end{array}$ & $\begin{array}{l}\mathrm{F} \\
\%\end{array}$ & $\begin{array}{l}0 \\
0\end{array}$ & $\begin{array}{l}7 \\
2.5\end{array}$ & $\begin{array}{l}22 \\
7.7\end{array}$ & $\begin{array}{l}65 \\
22.9\end{array}$ & $\begin{array}{l}190 \\
66.9\end{array}$ & 4.54 & $\begin{array}{l}\text { Her } \\
\text { zaman }\end{array}$ \\
\hline & Derste projeksiyon kullanabilirim. & $\begin{array}{l}\mathrm{F} \\
\%\end{array}$ & $\begin{array}{l}0 \\
0\end{array}$ & $\begin{array}{l}3 \\
1.1\end{array}$ & $\begin{array}{l}25 \\
8.8\end{array}$ & $\begin{array}{l}61 \\
21.5\end{array}$ & $\begin{array}{l}195 \\
68.7\end{array}$ & 4.57 & $\begin{array}{l}\text { Her } \\
\text { zaman }\end{array}$ \\
\hline & Ders sırasında öğrencinin & $\mathrm{F}$ & 0 & 2 & 24 & 75 & 183 & & \\
\hline & $\begin{array}{l}\text { motivasyonunu arttırmak için dijital } \\
\text { kaynakları kullanabilirim. }\end{array}$ & & 0 & .7 & 8.5 & 26.4 & 64.4 & 4.54 & zaman \\
\hline & $\begin{array}{l}\text { Cep telefonu vb. araçlarla çeşitli } \\
\text { içeriklere ulaşabilirim. }\end{array}$ & $\begin{array}{l}\mathrm{F} \\
\%\end{array}$ & $\begin{array}{l}1 \\
.4\end{array}$ & $\begin{array}{l}6 \\
2.1\end{array}$ & $\begin{array}{l}19 \\
6.7\end{array}$ & $\begin{array}{l}73 \\
25.7\end{array}$ & $\begin{array}{l}185 \\
65.1\end{array}$ & 4.53 & $\begin{array}{l}\text { Her } \\
\text { zaman }\end{array}$ \\
\hline & Ders içeriğine göre ihtiyacım olan & $\mathrm{F}$ & 0 & 3 & 28 & 92 & 161 & 444 & Her \\
\hline & materyali dijital ortamlarda bulabilirim & $\%$ & 0 & 1.1 & 9.9 & 32.4 & 56.7 & & zaman \\
\hline & Toplam & & & & & & & 4.06 & Siklıkla \\
\hline
\end{tabular}

Tablo 3 incelendiğinde öğretmen adaylarının dijital okuryazarlık öz-yeterlik ölçeğinin kaynak kullanabilme alt boyutunda yer alan bütün maddelere "Her zaman" cevabını verdikleri görülmektedir.

Öğretmen adaylarının dijital okuryazarlıklarının uygulama kullanabilme boyutunda frekans, yüzde ve madde ortalamaları dağılımı Tablo 4'de verilmiştir. 
Tablo 4. Ölçeğin üçüncü boyutu ( uygulama kullanabilme) ile ilgili yüzde, frekans ve madde ortalamaları

\begin{tabular}{|c|c|c|c|c|c|c|c|c|c|}
\hline & Boyutta yer alan maddeler & & 1 & 2 & 3 & 4 & 5 & $\mathbf{X}$ & Sonuç \\
\hline & Jpeg /Winzip gibi sıkıstırma & $f$ & 61 & 57 & 79 & 35 & 52 & & Arr \\
\hline & formatlarını kullanabilirim. & $\%$ & 21.5 & 20.1 & 27.8 & 12.3 & 18.3 & 2.85 & sira \\
\hline & Belgeleri farklı formatlara & $\mathrm{f}$ & 15 & 50 & 64 & 70 & 85 & & \\
\hline & çevirebilirim (örneğin wordden pdf’ye) & $\%$ & 5.3 & 17.6 & 22.5 & 24.6 & 29.9 & 3.56 & Siklikla \\
\hline & Sosyal İmleme uygulayabilirim & $\mathrm{f}$ & 24 & 41 & 64 & 65 & 90 & & \\
\hline & $\begin{array}{l}\text { (Sosyal İmlemenin amacı beğenilen } \\
\text { içeriklerin sosyal ortamda saklanıp } \\
\text { arşivlenmesidir.) }\end{array}$ & $\%$ & 8.5 & 14.4 & 22.5 & 22.9 & 31.7 & 3.54 & Siklikla \\
\hline & Hazırladığım bir videoyu dijital ortama & $\mathrm{f}$ & 22 & 43 & 56 & 65 & 98 & & \\
\hline$\stackrel{\mathscr{E}}{\underline{E}}$ & $\begin{array}{l}\text { yükleyebilirim(TeacherTube, } \\
\text { Videoegg, Selfcast) }\end{array}$ & $\%$ & 7.7 & 15.1 & 19.7 & 22.9 & 34.5 & 3.61 & Siklıkla \\
\hline 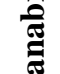 & $\begin{array}{l}\text { Derste web tabanlı interaktif oyun } \\
\text { oynatabilirim. }\end{array}$ & $\begin{array}{l}\mathrm{f} \\
\%\end{array}$ & $\begin{array}{l}11 \\
3.9\end{array}$ & $\begin{array}{l}54 \\
19.0\end{array}$ & $\begin{array}{l}67 \\
23.6\end{array}$ & $\begin{array}{l}75 \\
26.4\end{array}$ & $\begin{array}{l}77 \\
27.1\end{array}$ & 3.53 & Siklıkla \\
\hline $\bar{z}$ & Ders esnasında podcast & $\mathrm{f}$ & 21 & 36 & 69 & 58 & 100 & & \\
\hline 光 & $\begin{array}{l}\text { kullanabilirim.(Podcast'ler genellikle } \\
\text { orijinal ses veya görüntü kayıtlarından }\end{array}$ & $\%$ & & & & & & & \\
\hline & $\begin{array}{l}\text { oluşur; ancak bir TV ya da radyo } \\
\text { programının, dersin, performansın } \\
\text { veya başka bir etkinliğin kaydedilmiş } \\
\text { yayınları da olabilir.) }\end{array}$ & & 7.4 & 12.7 & 24.3 & 20.4 & 35.2 & 3.63 & Siklıkla \\
\hline & Eğitim amaçlı bir blog & $\mathrm{f}$ & 25 & 68 & 69 & 60 & 60 & & Ara \\
\hline & hazırlayabilirim. & $\%$ & 8.8 & 23.9 & 24.3 & 21.8 & 21.1 & 3.22 & sira \\
\hline & Dijital haritaları kullanabilirim & $\mathrm{f}$ & 13 & 26 & 43 & 74 & 128 & & \\
\hline & $\begin{array}{l}\text { (Google Maps, Community Walk, } \\
\text { ZeeMaps, Wayfaring, MapBuzz) }\end{array}$ & $\%$ & 4.6 & 9.2 & 15.1 & 26.1 & 45.1 & 3.97 & Siklıkla \\
\hline & Dijital ortamda & $\mathrm{f}$ & 8 & 33 & 68 & 79 & 96 & & \\
\hline & $\begin{array}{l}\text { Poster/Kartpostal/Kolaj } \\
\text { hazırlayabilirim }\end{array}$ & $\%$ & 2.8 & 11.6 & 23.9 & 27.8 & 33.8 & 3.78 & Siklıkla \\
\hline & Toplam & & & & & & & 3.52 & Siklıkla \\
\hline
\end{tabular}

Tablo 4 incelendiğinde öğretmen adaylarının dijital okuryazarlık öz-yeterlik ölçeğinin uygulama kullanabilme alt boyutuna çoğunlukla "Sıklıkla" cevabını verdikleri, sadece "Jpeg /Winzip gibi sıkıştırma formatlarını kullanabilirim" ve "Eğitim amaçlı bir blog hazırlayabilirim." maddelerine "Ara sıra " cevabını verdikleri görülmektedir.

Öğretmen adaylarının dijital okuryazarlıklarının destek boyutunda frekans, yüzde ve madde ortalamaları dağılımı Tablo 5'de verilmiştir. 
Tablo 5. Ölçeğin dördüncü boyutu ( destek) ile ilgili yüzde, frekans ve madde ortalamaları

\begin{tabular}{|c|c|c|c|c|c|c|c|c|c|}
\hline & Boyutta yer alan maddeler & & 1 & 2 & 3 & 4 & 5 & $\mathbf{X}$ & Sonuç \\
\hline \multirow{10}{*}{ 离 } & Öğrencilerime dijital ortamda eğitsel & f & 3 & 19 & 70 & 78 & 114 & \multirow[t]{2}{*}{3.98} & \multirow[t]{2}{*}{ Siklıkla } \\
\hline & Öğrencilerin öğrenmeyi evde devam & $\mathrm{f}$ & 2 & 22 & 62 & 97 & 101 & & \\
\hline & $\begin{array}{l}\text { ettirebilmeleri için dijital kaynak } \\
\text { kullanabilirim. }\end{array}$ & $\%$ & .7 & 7.7 & 21.8 & 34.2 & 35.6 & 3.96 & Siklıkla \\
\hline & Video konferans yöntemi ile tüm & $\mathrm{f}$ & 18 & 46 & 81 & 72 & 67 & \multirow{3}{*}{3.43} & \multirow{3}{*}{ Siklıkla } \\
\hline & öğrencilere ulaşabilirim. & $\%$ & 6.3 & 16.2 & 28.5 & 25.4 & 23.6 & & \\
\hline & Öğrencilerimin çalışmalarını dijital & f & 18 & 46 & 80 & 70 & 70 & & \\
\hline & 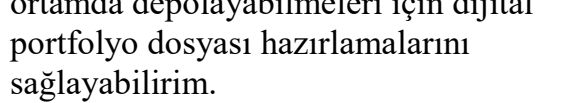 & $\%$ & 6.3 & 16.2 & 28.2 & 24.6 & 24.6 & 3.45 & Siklıkla \\
\hline & Öğrencileri dijital kaynakların kullanımı & $\mathrm{f}$ & 1 & 18 & 57 & 96 & 112 & \multirow[b]{2}{*}{4.05} & \multirow[b]{2}{*}{ Siklıkla } \\
\hline & hakkında bilgilendirebilirim. & $\%$ & .4 & 6.3 & 20.1 & 33.8 & 39.4 & & \\
\hline & Toplam & & & & & & & 3.77 & Siklıkla \\
\hline
\end{tabular}

Tablo 5 incelendiğinde öğretmen adaylarının dijital okuryazarlık öz-yeterlik ölçeğinin destek alt boyutunda yer alan bütün maddelere "Slkllkla" cevabını verdikleri görülmektedir. Yukarıda ölçeğin her bir alt boyutuna ait ölçek maddelerinden elde edilen puanları ile toplam puanlara yönelik öğretmen adaylarının düzeyleri verilmiştir. Ayrıca ölçeğin tümü göz önüne alındığında öğretmen adaylarının ölçekte aldıkları puan ortalaması 4.04 ve standart sapması ise .56 dır. Bu durum öğretmen adaylarının dijital okul yazarlık özyeterlik puanlarının sıklıkla düzeyinde olduğunu göstermektedir.

\section{Cinsiyet öğretmen adaylarının dijital okuryazarlık öz-yeterlikleri üzerinde anlamlı} bir farklılık oluşturmakta mıdır?

Öğretmen adaylarının dijital okuryazarlık öz-yeterlikleri üzerinde cinsiyetin anlamlı etkisi olup olmadığını belirlemek üzere yapılan Mann-Whitney U testi sonuçları Tablo 6'da verilmiştir.

Tablo 6 Öğretmen adaylarının cinsiyet açısından dijital okuryazarlık öz-yeterliklerine ilişkin Mann-Whitney U testi sonuçları

\begin{tabular}{|c|c|c|c|c|c|c|}
\hline Dijital Okuryazarlık & Cinsiyet & $\mathbf{N}$ & $\begin{array}{l}\text { Sira } \\
\text { Ortalaması }\end{array}$ & $\begin{array}{l}\text { Sira } \\
\text { Toplamı }\end{array}$ & $\mathbf{U}$ & $\mathbf{P}$ \\
\hline \multirow{2}{*}{ Toplam } & Kiz & 233 & 138.41 & 30866.50 & \multirow{2}{*}{5890.500} & \multirow{2}{*}{.109} \\
\hline & Erkek & 61 & 157.43 & 9603.50 & & \\
\hline \multirow{2}{*}{ Üretim(1.Boyut) } & $\mathrm{K} 1 \mathrm{z}$ & 233 & 143.32 & 31960.50 & \multirow{2}{*}{6618.500} & \multirow{2}{*}{.747} \\
\hline & Erkek & 61 & 139.50 & 8509.50 & & \\
\hline \multirow{2}{*}{$\begin{array}{l}\text { Kaynak } \\
\text { Kullanabilme(2.Boyut) }\end{array}$} & Kiz & 233 & 143.08 & 31907.50 & \multirow{2}{*}{6671.500} & \multirow{2}{*}{.817} \\
\hline & Erkek & 61 & 140.37 & 8562.50 & & \\
\hline \multirow{2}{*}{$\begin{array}{l}\text { Uygulama } \\
\text { Kullanabilme(3.Boyut) }\end{array}$} & $\mathrm{K} 1 \mathrm{z}$ & 233 & 133.02 & 29664.50 & \multirow{2}{*}{4688.500} & \multirow{2}{*}{.000} \\
\hline & Erkek & 61 & 177.14 & 10805.50 & & \\
\hline \multirow{2}{*}{ Destek (4. Boyut) } & $\mathrm{K} 1 \mathrm{z}$ & 233 & 139.80 & 31174.50 & \multirow{2}{*}{6198.500} & \multirow{2}{*}{.287} \\
\hline & Erkek & 61 & 152.39 & 9295.50 & & \\
\hline
\end{tabular}

$* \mathrm{p}<0.05$ 
Tablo 6'ya göre cinsiyet öğretmen adaylarının dijital okuryazarlık öz-yeterlik beceri düzeyleri üzerinde sadece uygulama kullanabilme boyutunda anlamlı bir farklılığa neden olmaktadır $\mathrm{p}<0.05$, diğer boyutlarda anlamlı bir farklılığa neden olmamaktadır $(\mathrm{p}<0.05)$.

3. Öğrenim görmekte oldukları bölüm dijital okuryazarlık öz-yeterlikleri üzerinde anlamlı bir farklılık oluşturmakta mıdır?

Öğretmen adaylarının dijital okuryazarlık öz-yeterlikleri üzerinde öğrenim görmekte oldukları bölümün anlamlı etkisi olup olmadığını belirlemek üzere yapılan Kruskal-Wallis Testi Analizi sonuçları Tablo 7'de verilmiştir.

Tablo 7. Öğretmen adaylarının öğrenim görmekte oldukları bölüm türü açısından dijital okuryazarlık öz-yeterlikleri ilişkin Kruskal-Wallis testi analizi sonuçları

\begin{tabular}{|c|c|c|c|c|c|c|c|}
\hline $\begin{array}{ll}\text { Ölçek } & \text { ve } \\
\text { boyutları }\end{array}$ & Bölüm & $\mathbf{N}$ & Sira & S.S. & $\mathbf{X}^{2}$ & $\mathbf{p}$ & $\begin{array}{l}\text { Anlam } \\
\text { Fark }\end{array}$ \\
\hline \multirow[t]{7}{*}{ Toplam Puan } & 1.Sınıf Öğr. & 61 & 152.39 & 55739 & 28.493 & .000 & $2-5$ \\
\hline & 2. Bil.Tek. Öğr. & 52 & 96.33 & & & & $2-1$ \\
\hline & 3. Matematik Öğr. & 52 & 126.80 & & & & $2-4$ \\
\hline & 4.Fen Bil. Öğr. & 51 & 171.11 & & & & $2-6$ \\
\hline & 5.Sosyal Bilg. & 40 & 156.13 & & & & \\
\hline & 6. Türkçe Öğr. & 28 & 164.30 & & & & \\
\hline & Toplam & 284 & & & & & \\
\hline \multirow[t]{7}{*}{ Üretim } & 1.Sınıf Öğr. & 61 & 161.61 & 69313 & 32.397 & .000 & $2-5$ \\
\hline & 2. Bil.Tek Öğr. & 52 & 96.06 & & & & $2-1$ \\
\hline & 3. Matematik Öğr. & 52 & 120.09 & & & & $2-4$ \\
\hline & 4.Fen Bil. Öğr. & 51 & 163.54 & & & & $2-6$ \\
\hline & 5.Sosyal Bilg. & 40 & 152.98 & & & & \\
\hline & 6. Türkçe. Öğgr. & 28 & 175.45 & & & & \\
\hline & Toplam & 284 & & & & & \\
\hline Kaynak & 1.Sinıf Öğr. & 61 & 159.48 & 40160 & 20.966 & .001 & $2-6$ \\
\hline \multirow[t]{6}{*}{ Kullanabilme } & 2. Bil.Tek Öğr. & 52 & 101.16 & & & & $2-1$ \\
\hline & 3. Matematik Öğr. & 52 & 136.23 & & & & $2-4$ \\
\hline & 4.Fen Bil. Öğr. & 51 & 164.10 & & & & \\
\hline & 5.Sosyal Bilg. & 40 & 140.66 & & & & \\
\hline & 6. Türkçe. Öğr. & 28 & 157.20 & & & & \\
\hline & Toplam & 284 & & & & & \\
\hline Uygulama & 1.Sinıf Öğr. & 61 & 138.68 & 83515 & 19.217 & .002 & $2-5$ \\
\hline \multirow[t]{6}{*}{ Kullanabilme } & 2. Bil.Tek Öğgr. & 52 & 108.19 & & & & $2-5$ \\
\hline & 3. Matematik Öğr. & 52 & 130.90 & & & & \\
\hline & 4.Fen Bil. Öğr. & 51 & 164.75 & & & & \\
\hline & 5.Sosyal Bilg. & 40 & 169.50 & & & & \\
\hline & 6. Türkçe. Öğr. & 28 & 156.98 & & & & \\
\hline & Toplam & 284 & & & & & \\
\hline \multirow[t]{7}{*}{ Destek } & 1.Sinıf Öğr. & 61 & 147.19 & 79048 & 26.065 & .000 & $2-4$ \\
\hline & 2. Bil.Tek Öğr. & 52 & 107.10 & & & & \\
\hline & 3. Matematik Öğr. & 52 & 127.58 & & & & \\
\hline & 4.Fen Bil. Öğr. & 51 & 185.67 & & & & \\
\hline & 5.Sosyal Bilg. & 40 & 148.16 & & & & \\
\hline & 6. Türkçe. Öğr. & 28 & 139.04 & & & & \\
\hline & Toplam & 284 & & & & & \\
\hline
\end{tabular}

$* \mathrm{p}<0.05$

Tablo 7 incelendiğinde öğretmen adaylarının öğrenim görmekte oldukları bölüm türüne göre dijital okuryazarlık öz-yeterliklerinin ölçeğin tüm alt boyutlarında anlamlı bir 
farklılaşma gösterdiği belirlenmiştir. Bu farklılığın nereden kaynaklandığını belirlemek için hipotez testi yapılmış ve elde edilen sonuçlar tabloda gösterilmiştir. Farkın kaynağının tüm alt boyutlarda Bilgisayar ve Öğretim Teknolojileri Eğitimi Öğretmenliği lehine anlamlı olduğu görülmektedir.

4. Öğretmen adaylarının anne eğitim durumları dijital okuryazarlı öz-yeterlikleri üzerinde anlamlı bir farklılık oluşturmakta mıdır?

Öğretmen adaylarının dijital okuryazarlık öz-yeterlikleri üzerinde anne eğitim durumunun anlamlı etkisi olup olmadığını belirlemek üzere yapılan Kruskal-Wallis Testi Analizi sonuçları Tablo 8'de verilmiştir.

Tablo 8. Öğretmen adaylarının anne eğitim durumu açısından dijital okuryazarlık özyeterlikleri ilişkin Kruskal-Wallis testi analizi sonuçları

\begin{tabular}{|c|c|c|c|c|c|c|}
\hline $\begin{array}{ll}\begin{array}{l}\text { Ölçek } \\
\text { boyutları }\end{array} & \text { ve } \\
\end{array}$ & Anne Eğitim Durumu & $\mathbf{N}$ & Sira & S.S. & $\mathbf{X}^{2}$ & $\mathbf{p}$ \\
\hline \multirow[t]{5}{*}{ Toplam Puan } & 1.İlkokul & 177 & 138.46 & .55739 & 2.694 & .441 \\
\hline & 2.Ortaokul & 50 & 145.27 & & & \\
\hline & 3.Lise & 45 & 146.09 & & & \\
\hline & 4.Üniversite & 12 & 177.04 & & & \\
\hline & Toplam & 284 & & & & \\
\hline \multirow[t]{5}{*}{ Üretim } & 1.İlkokul & 177 & 140.49 & .69313 & 399 & .941 \\
\hline & 2.Ortaokul & 50 & 147.27 & & & \\
\hline & 3.Lise & 45 & 142.88 & & & \\
\hline & 4.Üniversite & 12 & 150.79 & & & \\
\hline & Toplam & 284 & & & & \\
\hline Kaynak & 1.ílkokul & 177 & 140.84 & .40160 & 1.526 & .676 \\
\hline \multirow{4}{*}{ Kullanabilme } & 2.Ortaokul & 50 & 143.18 & & & \\
\hline & 3.Lise & 45 & 140.79 & & & \\
\hline & 4.Üniversite & 12 & 170.54 & & & \\
\hline & Toplam & 284 & & & & \\
\hline Uygulama & 1.ílkokul & 177 & 137.72 & .83515 & 4.775 & .189 \\
\hline \multirow{4}{*}{ Kullanabilme } & 2.Ortaokul & 50 & 143.80 & & & \\
\hline & 3.Lise & 45 & 147.19 & & & \\
\hline & 4.Üniversite & 12 & 189.96 & & & \\
\hline & Toplam & 284 & & & & \\
\hline \multirow[t]{5}{*}{ Destek } & 1.İlkokul & 177 & 139.21 & .79048 & 2.092 & .553 \\
\hline & 2.Ortaokul & 50 & 146.38 & & & \\
\hline & 3.Lise & 45 & 142.94 & & & \\
\hline & 4.Üniversite & 12 & 173.25 & & & \\
\hline & Toplam & 284 & & & & \\
\hline
\end{tabular}

Tablo 8 incelendiğinde öğretmen adaylarının anne eğitim durumuna göre dijital okuryazarlık öz-yeterlikleri ilişkin analiz sonuçlarında ölçeğin tümünde anne eğitim durumu dijital okuryazarlık öz-yeterliliği üzerinde anlamlı bir etki oluşturmamaktadır.

5. Öğretmen adaylarının baba eğitim durumları dijital okuryazarlı öz-yeterlikleri üzerinde anlamlı bir farklılık oluşturmakta mıdır?

Öğretmen adaylarının dijital okuryazarlık öz-yeterlikleri üzerinde baba eğitim durumunun anlamlı etkisi olup olmadığını belirlemek üzere yapılan Kruskal-Wallis Testi Analizi sonuçları Tablo 9'da verilmiştir. 
Tablo 9. Öğretmen adaylarının baba eğitim durumu açısından dijital okuryazarlık özyeterlikleri ilişkin Kruskal-Wallis testi analizi sonuçları

\begin{tabular}{|c|c|c|c|c|c|c|}
\hline $\begin{array}{ll}\text { Ölçek } & \text { ve } \\
\text { boyutları } & \end{array}$ & Baba Eğitim Durumu & $\mathbf{N}$ & Sira & S.S. & $\mathbf{X}^{2}$ & $\mathbf{p}$ \\
\hline \multirow[t]{5}{*}{ Toplam Puan } & 1.İlkokul & 103 & 149.16 & .55739 & 2.639 & .451 \\
\hline & 2.Ortaokul & 53 & 128.90 & & & \\
\hline & 3.Lise & 76 & 138.51 & & & \\
\hline & 4.Üniversite & 52 & 149.01 & & & \\
\hline & Toplam & 284 & & & & \\
\hline \multirow[t]{5}{*}{ Üretim } & 1.İlkokul & 103 & 149.09 & .69313 & 1.570 & .666 \\
\hline & 2.Ortaokul & 53 & 136.78 & & & \\
\hline & 3.Lise & 76 & 135.39 & & & \\
\hline & 4.Üniversite & 52 & 145.65 & & & \\
\hline & Toplam & 284 & & & & \\
\hline Kaynak & 1.ílkokul & 103 & 145.76 & .40160 & 1.860 & .602 \\
\hline \multirow[t]{4}{*}{ Kullanabilme } & 2.Ortaokul & 53 & 135.96 & & & \\
\hline & 3.Lise & 76 & 135.68 & & & \\
\hline & 4.Üniversite & 52 & 152.68 & & & \\
\hline & Toplam & 284 & & & & \\
\hline Uygulama & 1.İlkokul & 103 & 150.09 & .83515 & 3.133 & .372 \\
\hline \multirow[t]{4}{*}{ Kullanabilme } & 2.Ortaokul & 53 & 126.05 & & & \\
\hline & 3.Lise & 76 & 141.20 & & & \\
\hline & 4.Üniversite & 52 & 146.13 & & & \\
\hline & Toplam & 284 & & & & \\
\hline \multirow[t]{5}{*}{ Destek } & 1.ílkokul & 103 & 147.85 & .79048 & 2.959 & .398 \\
\hline & 2.Ortaokul & 53 & 126.31 & & & \\
\hline & 3.Lise & 76 & 141.42 & & & \\
\hline & 4.Üniversite & 52 & 149.98 & & & \\
\hline & Toplam & 284 & & & & \\
\hline
\end{tabular}

Tablo 9 incelendiğinde öğretmen adaylarının baba eğitim durumuna göre dijital okuryazarlık öz-yeterlikleri ilişkin analiz sonuçlarında ölçeğin tümünde baba eğitim durumu dijital okuryazarlık öz-yeterliliği üzerinde anlamlı bir etki oluşturmamaktadır.

6. Öğretmen adaylarının bilgisayar erişim imkânları dijital okuryazarlık özyeterlikleri üzerinde anlamlı bir farklılık oluşturmakta mıdır?

Öğretmen adaylarının dijital okuryazarlık öz-yeterlikleri üzerinde bilgisayar erişim imkanının anlamlı etkisi olup olmadığını belirlemek üzere yapılan Mann-Whitney $U$ sonuçları Tablo 10'da verilmiştir. 
Tablo 10. Öğretmen adaylarının bilgisayar erişim imkanı açısından dijital okuryazarlık özyeterlikleri Mann-Whitney u testi sonuçları

\begin{tabular}{lllllll}
\hline Dijital Okuryazarlık & Bilgisayar & N & $\begin{array}{l}\text { Sira } \\
\text { Ortalamas }\end{array}$ & $\begin{array}{l}\text { Sira } \\
\text { Toplamı }\end{array}$ & U & P \\
\hline Toplam & Var & 239 & 147.00 & 35133.50 & 4301.500 & .033 \\
& Yok & 45 & 118.59 & 5336.50 & & \\
Üretim(1.Boyut) & Var & 239 & 147.67 & 35293.50 & 4141.500 & .014 \\
& Yok & 45 & 115.03 & 5176.50 & & \\
Kaynak & Var & 239 & 144.83 & 34615.00 & 4820.000 & .265 \\
Kullanabilme(2.Boyut) & Yok & 45 & 130.11 & 5855.00 & & \\
Uygulama & Var & 239 & 145.52 & 34780.00 & 4655.000 & .152 \\
Kullanabilme(3.Boyut) & Yok & 45 & 126.44 & 5690.00 & & .058 \\
Destek (4. Boyut) & Var & 239 & 146.49 & 35012.00 & 4423.000 & .058 \\
\hline
\end{tabular}

*p $<0.05$

Tablo 10 incelendiğinde bilgisayar erişim imkânının öğretmen adaylarının dijital okuryazarlık öz-yeterlikleri üzerinde üretim (.014) boyutunda ve ölçeğin toplam puanında (.033) anlamalı bir farklılık oluşturduğu görülmektedir. Diğer boyutlarda ise anlamlı farklılık görülmemektedir.

7. Öğretmen adaylarının mezun olduklarl okul türü dijital okuryazarlı özyeterlikleri üzerinde anlamlı bir farklılık oluşturmakta mıdır?

Öğretmen adaylarının dijital okuryazarlık öz-yeterlikleri üzerinde mezun oldukları okul türünün anlamlı etkisi olup olmadığını belirlemek üzere yapılan Kruskal-Wallis Testi Analizi sonuçları Tablo 11'da verilmiştir.

Tablo 11 Öğretmen adaylarının mezun olduğu lise türü açısından dijital okuryazarlık özyeterlikleri ilişkin Kruskal-Wallis testi analizi sonuçları

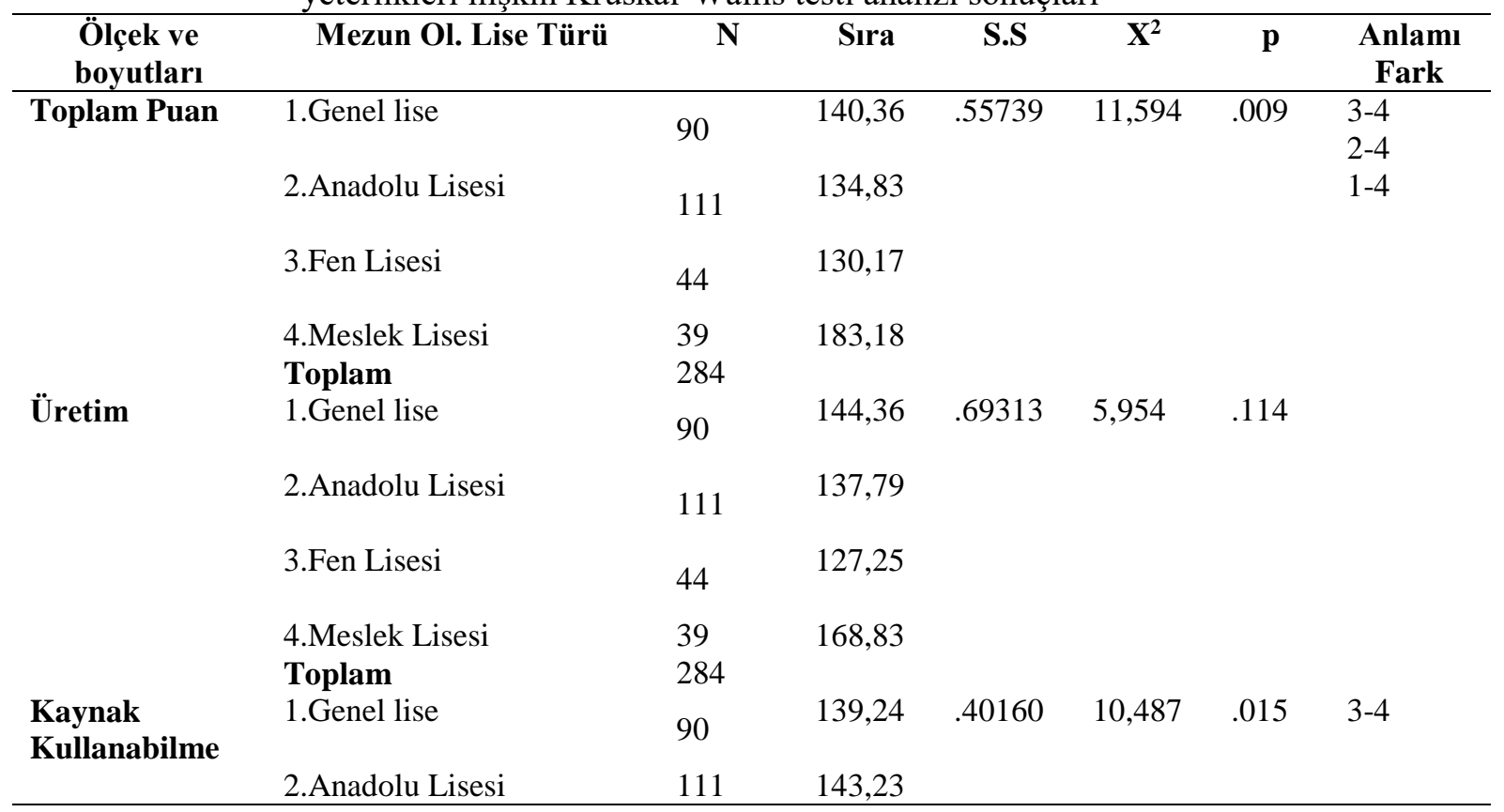




\begin{tabular}{llllllll} 
& 3.Fen Lisesi & 44 & 118,16 & & & & \\
& 4.Meslek Lisesi & 39 & 175,38 & & & & \\
Uygulama & Toplam & 284 & & & & & \\
Kullanabilme & 1.Genel lise & 90 & 138,44 & .83515 & 9,930 & .019 & $2-4$ \\
& 2.Anadolu Lisesi & 111 & 132,81 & & & & $1-4$ \\
& 3.Fen Lisesi & 44 & 141,99 & & & & \\
Destek & 4.Meslek Lisesi & 39 & 180,03 & & & & \\
& Toplam & 284 & & & & \\
& 1.Genel lise & 90 & 139,38 & .79048 & 14,461 & .002 & $2-4$ \\
& 2.Anadolu Lisesi & 111 & 129,42 & & & & \\
& 3.Fen Lisesi & 44 & 142,45 & & & & \\
& 4.Meslek Lisesi & 39 & 186,96 & & & & \\
Toplam & 284 & & & & & \\
\hline
\end{tabular}

Tablo 11 incelendiğinde öğretmen adaylarının mezun olduğu lise türü açısından dijital okuryazarlık öz-yeterliklerinin destek, uygulama kullanabilme, kaynak kullanabilme ve toplam puanları üzerinde anlamlı farklılık gösterdiği, üretim alt boyutunda ise anlamlı farklılık göstermediği tespit edilmiştir. Bu farklılığın nereden kaynaklandığını belirlemek için hipotez testi yapılmış ve elde edilen sonuçlar tabloda gösterilmiştir. Farkın kaynağının meslek lisesi ve diğer liseler arasında, diğer liselerin lehine olduğu görülmektedir.

\section{Sonuç Tartışma ve Öneriler}

Bu çalışmada öğretmen adaylarının dijital okur-yazarlık öz-yeterlilikleri düzeylerinin dağılımı ve bu düzeylerin cinsiyet, öğrenim görmekte oldukları bölüm, anne ve baba eğitim durumu, mezun oldukları okul türü, internet ve bilgisayar erişim olanakları açısından anlamlı bir farklılık gösterip göstermediği incelenmiştir. Ölçeğin her bir alt boyutuna ait ölçek maddelerinden elde edilen puanları ile toplam puanlara yönelik öğretmen adaylarının düzeyleri incelendiğinde tüm alt boyutlarda öğrenci düzeylerinin sıklıkla aralığında olduğu görülmektedir. Ayrıca ölçeğin tümü göz önüne alındığında öğretmen adaylarının ölçekte aldıkları puan ortalaması 4.04 ve standart sapması ise .56 dır. $\mathrm{Bu}$ durum öğretmen adaylarının dijital okul yazarlık öz-yeterlik puanlarının toplamda da sıklıkla düzeyinde olduğunu göstermektedir.

Çalışmanın birinci alt problemi olarak öğretmen adaylarının dijital okuryazarlık özyeterlikleri beceri düzeyleri incelenmiştir. Öğretmen adaylarının dijital okuryazarlık özyeterlik ölçeğinin üretim alt boyutuna çoğunlukla "Sıklıkla" cevabını verdikleri, sadece "Öğrenme ortamını zenginleştirmek için dijital kaynak kullanabilirim" ve "Anlattığım dersi dijital ortamda ögrencinin daha sonra da dinleyebilmesini sağlamak için depolayabilirim" maddelerine "Her zaman" cevabını verdikleri görülmektedir. Ölçeğinin kaynak kullanabilme alt boyutunda yer alan bütün maddelere "Her zaman" cevabını verdikleri, uygulama kullanabilme alt boyutuna çoğunlukla "Sıklıkla" cevabını verdikleri, sadece "Jpeg /Winzip gibi sıkıştırma formatlarını kullanabilirim " ve "Eğitim amaçlı bir blog hazırlayabilirim." 
maddelerine "Ara sıra " cevabını verdikleri görülmektedir. Son olarak destek alt boyutunda yer alan bütün maddelere öğretmen adaylarının "Slkllkla" cevabını verdikleri görülmektedir. $\mathrm{Bu}$ durum öğretmen adaylarının dijital okuryazarlık öz-yeterliliklerinin yüksek olduğunu göstermektedir. Alanyazında yer alan çalışmalarda öğretmen adaylarının dijital okuryazarlıklarının yüksek düzeyde olmasının önemli olduğu ifade edilmektedir (Khalid, Slættalíð, Parveen \& Hossain, 2015). Ayrıca alanyazında öğretmen adaylarının dijital okuryazarlık beceri düzeylerinin yüksek olması mesleki gelişim açısından önemli olduğu ifade edilmektedir (Svensson \& Baelo, 2015).Bununla birlikte dijital okuryazarlığın öğretmen eğitim programında temel olarak yer alması gerektiği ve öğretmen adaylarının dijital okuryazarlığ (Campbell, 2016). Rambousek, Štípek, \& Vaňková (2016) tarafından yapılan çalışmada ise öğretmen adayları kendi dijital okuryazarlık düzeylerini minimum olarak ifade etmektedirler. Çalışmada ayrıca dijital okuryazarlığın ölçülmesinin gerçek düzeyi yansıtamayabileceği ifade edilmektedir Gasaymeh, Al-Tawel, Al-Moghrabi \& Al-Ghonmein, (2017) tarafindan yapılan çalışmada ise üniversite öğrencilerinin dijital teknolojilere yönelik olumlu bir tutuma sahip olduklarını belirtmektedir.

Çalışmanın ikinci alt problemi olarak cinsiyetin dijital okuryazarlık öz-yeterlikleri üzerinde etkisi incelenmiştir. Elde edilen sonuca göre cinsiyet öğretmen adaylarının dijital okuryazarlık öz-yeterlikleri düzeyleri üzerinde sadece uygulama kullanabilme boyutunda anlamlı bir farklılığa neden olmaktadır diğer boyutlarda anlamlı bir farklılığa neden olmamaktadır. Kubiatko vd. (2010) tarafından yapılan çalışmada erkek üniversite öğrencilerinin bilgi ve iletişim teknoloji puanlarının yüksek olduğu, Çetin, Çalışkan ve Menzi (2012) tarafından yapılan çalışmada ise erkek öğretmen adaylarının bayan öğretmen adaylarına göre daha yüksek teknoloji yeterliliğine sahip oldukları ancak teknolojiye yönelik tutumlarının ise cinsiyet değişkenine göre farklılık göstermediği ifade edilmektedir. Zin vd.(2000) tarafından yapılan çalışmada erkeklerin bilgisayar okuryazarlığı kızlardan daha yüksek olduğu belirtilmektedir. Comber, Hargreaves, \& Dorn, (1997) ise çalışmalarında erkeklerin bilgisayarlara yönelik tutumlarının daha yüksek olduğunu, Smith \& Necessary (1996) ise erkeklerin bilgisayar okuryazarlığının kızlardan daha yüksek olduğunu belirtmektedir.

Alanyazında yer alan diğer bazı çalışmalarda cinsiyetin dijital okuryazarlık üzerinde etkili olmadığını belirtilmektedir (Maden, Banaz \& Maden, 2018; Karasu ve Arıkan, 2016). Ayrıca Maxwell, \& Maxwell (2014) üniversitede öğrenim gören kız ve erkek öğrencilerin bilgisayarı öğrenme şekillerinin farklı olduğunu ve verilecek eğitimin de bu farklılığa hitap etmesi gerektiğini belirtmektedir. Volman (1997) ise bilgisayar ve bilgi okuryazarlığının kız ve erkekler için eşit olması gerektiğini ancak erkeklerde daha iyi olmasının nedeninin bilgisayarın maskülen olarak görülmesine ve erkeklerin oyun bağımlılığına bağlı olabileceğini belirtmektedir.

Çalışmanın üçüncü alt problemi olarak öğretmen adaylarının öğrenim görmekte oldukları bölümün dijital okuryazarlık öz-yeterlikleri üzerinde anlamlı bir farklılık oluşturup oluşturmadığı incelenmiştir. Öğretmen adaylarının öğrenim görmekte oldukları bölüm türüne göre dijital okuryazarlık öz-yeterliklerinin ölçeğin tüm alt boyutlarında anlamlı bir farklılaşma gösterdiği belirlenmiştir. Bu farklılığın nereden kaynaklandığını belirlenmiştir. Elde edilen sonuçlara göre farkın kaynağının tüm alt boyutlarda diğer bölümlerle (Fen Bilgisi Öğretmenliği, Sosyal Bilgiler Öğretmenliği, Sınıf Öğretmenliği ve Türkçe 
Öğretmenliği) ile Bilgisayar ve Öğretim Teknolojileri Eğitimi Öğretmenliği arasında ve Bilgisayar ve Öğretim Teknolojileri Eğitimi Öğretmenliği lehine anlamlı olduğu görülmektedir. Çetin, Çalışkan ve Menzi (2012) çalışmalarında öğretmen adaylarının öğrenim gördükleri bölümlere göre teknoloji yeterlilikleri ve teknolojiye yönelik tutumları arasında oluşan farklılaşmayı incelemiştir. Çalışma sonucunda fen bilgisi öğretmenliği ve sınıf öğretmenliği bölümlerinde öğrenim gören öğretmen adaylarının sosyal bilgiler öğretmenliği bölümünde öğrenim gören öğretmen adaylarından teknoloji yeterlilik olarak daha üst seviyede oldukları belirtilmiştir. Alanyazında farklı olarak Karasu ve Arıkan (2016) tarafından yapılan çalışmada lisans programının öğretmen adaylarının medya okuryazarlığı üzerinde anlamlı bir etki oluşturmadığı belirtilmektedir.

Çalışmanın dördüncü alt problemi olarak öğretmen adaylarının anne eğitim durumları dijital okuryazarlık öz-yeterlikleri üzerinde anlamlı bir farklılık oluşturup oluşturmadığı incelenmiştir. Öğretmen adaylarının anne eğitim durumu dijital okuryazarlık öz-yeterlikleri üzerinde anlamlı bir farklılık oluşturmamaktadır. Çalışmanın beşinci alt problemi olarak öğretmen adaylarının baba eğitim durumlarının dijital okuryazarlık özyeterlikleri üzerinde anlamlı bir farklılık oluşturup oluşturmadığ incelenmiştir. Çalışmada elde edilen sonuç öğretmen adaylarının baba eğitim durumu dijital okuryazarlık özyeterlikleri üzerinde anlamlı bir etki oluşturmamaktadır. Alanyazında yapılan çalışmalar incelendiğinde ailenin dijital okuryazarlığının önemli olduğunun vurgulandığ görülmektedir. Carizzo (2012) ve López, Robles, Gómez, \& Hernández, (2017) çalışmalarında ailelerin dijital ortamlarda yetersiz olduklarını belirtmektedirler. Andrade (2004) ise öğrenciler ve aileler arasında dijital okuryazarlık açısından bir jenerasyon boşluğu olduğunu, Dinçer (2012) ailelerin öğrencilerin aksine bilgisayar okuryazarlık düzeylerinin düşük olduğunu, bilgisayar okuryazarlığı yüksek ailelerin her zaman öğrencilerine yardım etmediklerini belirtmektedir. Ayrıca Schartman (2012) ise dijital okuryazarlığ yüksek olan ailenin öğrenciyi daha iyi takip edebileceğini, eğitim süreci ile ilgili okuldan ve öğretmenlerinden daha fazla bilgi alabileceğini ve onları daha iyi destekleyebileceğini belirtmektedir. Ragnedda and Muschert (2013) ailenin dijital yetersizliğinin öğrenciyi de olumsuz yönde etkilediğini ifade ederken, Mikelic Preradovic, Lešin, \& Šagud (2016) ise ailenin sosyo-ekonomik durumunun, kültürel yapısının farklı olmasının öğrencinin dijital teknolojilere ulaşmasını engelleyebileceğini belirtmektedir. Kumpulainen \& Gillen, (2017) de ailenin dijital okuryazarlık düzeyinin ev ortamında öğrenci için erken yaşlardan itibaren etkili olduğunu belirtmektedir.

Çalışmanın altıncı alt problemi olarak öğretmen adaylarının bilgisayar erişim imkânlarının dijital okuryazarlık öz-yeterlikleri üzerinde anlamlı bir farklılık oluşturup oluşturmadığı incelenmiştir. Elde edilen sonuç bilgisayar erişim imkânının öğretmen adaylarının dijital okuryazarlık öz-yeterlikleri üzerinde üretim boyutunda ve ölçeğin toplam puanında anlamalı bir farklılık oluşturmaktadır. Bu durumda öğrencinin bilgisayar kullanmamasının onun dijital materyal üretmesine engel olduğu ve bu nedenle anlamlı bir fark oluş̧turduğu ifade edilebilir. Diğer alt boyutlarda ise anlamlı farkl1lık görülmemektedir. Dinçer (2012) tarafından yapılan çalışmada bilgisayarı olmayan öğrencilerin bilgisayar okuryazarlık düzeylerinin düşük olduğunu belirtmektedir.

Çalışmanın yedinci alt problemi olarak öğretmen adaylarının mezun oldukları okul türünün dijital okuryazarlık öz-yeterlikleri üzerinde anlamlı bir farklılık oluşturup oluşturmadığı incelenmiştir. Çalışmadan elde edilen sonuç öğretmen adaylarının mezun olduğu lise türünün dijital okuryazarlık öz-yeterliklerinin destek, uygulama kullanabilme, kaynak kullanabilme ve toplam puanları üzerinde anlamlı farklılık gösterdiği, üretim alt 
boyutunda ise anlamlı farklılık göstermediğidir. Farkın kaynağının meslek lisesi ve diğer liseler arasında, diğer liselerin lehine olduğu görülmektedir. Araştırmada elde edilen bu sonuç doğrultusunda meslek liselerinde yer alan zorunlu bilgisayar dersinin (Korkmaz ve Mahiroğlu, 2009) öğrencilerin dijital okuryazarlığını etkilemediğini söylenebilir. Bu çalışmada elde edilen sonuçlar 1şı̆̆ında öğretmen adaylarının dijital okuryazarlık özyeterliklerinin yükseltilmesi önerilmektedir. Bu durum öğretmen adaylarının teknolojik pedagojik alan yeterliliklerinin gelişmesine katkı sağlayabilir. Ayrıca bu sayede öğretmen adaylarının mesleki gelişimi de olumlu yönde etkilenebilir.

\section{Kaynakça}

Acar, Ç. (2015). Anne ve babaların ilkokul ortaokul ve lise ögrrencisi çocukları ile kendilerinin dijital okuryazarlıklarına ilişskin görüşleri (Yayımlanmamış yüksek lisans tezi). Ankara Üniversitesi Eğitim Bilimleri Enstitüsü, Ankara.

Atif, Y., \& Chou, C. (2018). Digital Citizenship: Innovations in Education, Practice, and Pedagogy. Journal of Educational Technology \& Society, 21(1), 152-154.

Andrade, B. (2004). Analfabetismo tecnológico: efecto de las tecnologías de información. Actualidad contable FACES, 7(8).

Campbell, E. (2016). Pre-service teachers' perceptions and practices: integrating digital literacy into English education(Unpublished Doctoral dissertation). University of Cape Town.

Carrizo, M. (2012). Las redes sociales como factor determinante de transgresión en la comunicación entre adolescentes El fenómeno de Facebook y su influencia (Tesis Pregrado). Facultad de Ciencias de la Educación y de la Comunicación Social. Universidad del Salvador. Buenos Aires. Recuperado de http://www.usal.edu.ar/archivos/di/carrizo_ mercedes.pdf

Cohen, L. M., \& Manion, L. \& Morrison, K.(2007). Research methods in education, 6.

Comber, C., Colley, A., Hargreaves, D. J., \& Dorn, L. (1997). The effects of age, gender and computer experience upon computer attitudes. Educational Research, 39(2), 123-133

Çetin, O., Çalışkan, E., \& Menzi, N. (2012). Öğretmen adaylarının teknoloji yeterlilikleri ile teknolojiye yönelik tutumları arasındaki ilişki. İlköğretim Online, 11(2).

Dincer, S. (2012). A study of the relationship between pupils and parents' computer literacy level and use. Procedia-Social and Behavioral Sciences, 46, 484-489.

Etikan, I., Musa, S. A., \& Alkassim, R. S. (2016). Comparison of convenience sampling and purposive sampling. American Journal of Theoretical and Applied Statistics, 5(1), 1-4.

Ferrari, A. (2012). Digital competence in practice: An analysis of frameworks. Luxembourg: Publications Office of the European Union http://dx.doi.org/10.2791/82116 JRC IPTS.

Gasaymeh, A. M. M., Al-Tawel, A. M., Al-Moghrabi, K. G., \& Al-Ghonmein, A. M. (2017). University students' perceptions of the use of digital technologies in their formal learning: a developing country perspective. International Journal of Learning and Development, 7(3), 149-164.

Güneş, E., \& Bahçivan, E. (2018). A mixed research-based model for pre-service science teachers' digital literacy: Responses to "which beliefs" and "how and why they interact" questions. Computers \& Education, 118, 96-106.

International Society for Technology in Education. (2007). National educational technology standards for students. ISTE (Interntl Soc Tech Educ).

Jackson, S.L. (2015). Research methods and statistics: A critical thinking approach. Cengage Learning. 
Karasu, M. ve Arıkan, D. (2016). Öğretmen adaylarının sosyal medya kullanım durumları ve medya okuryazarlık düzeyleri arasındaki ilişkinin incelenmesi.Ege Eğitim Dergisi ,17 (2), 549-566.

Khalid, S., Slættalíð, T. , Parveen, M. \& Hossain, M.S. (2015). A systematic review and meta-analysis of teachers' development of digital literacy. Kasım 2015 Innovations in Digital Learning for Inclusion 1st D4|Learning International Conference Paper. DOI: 10.13140/RG.2.1.2421.5120.

Korkmaz, Ö., Mahiroğlu, A. (2009). Üniversiteyi Yeni Kazanmış Öğrencilerin Bilgisayar Okuryazarlık Düzeyleri. Kastamonu Eğitim Dergisi, 17 (3), 983-1000.

Kubiatko, M., Uşak, M., Yılmaz, K. ve Tasar, M. F. (2010). A cross-national study of Czech and Turkish university students' attitudes towards ict used in science subjects. Journal of Baltic Science Education, 9(2), 119-134.

Kumpulainen, K., \& Gillen, J. (2017). Young children's digital literacy practices in the home: a review of the literature. COST ACTION ISI1410 DigiLitEY.

Leffler, M. E. (2015). Digitally divided in Jackson: Are students getting the digital literacy skills they need to succeed? (Unpublished Doctoral dissertation). Jackson State University.

Lewis, T. E., \& Alirezabeigi, S. (2018). Studying with the Internet: Giorgio Agamben, education, and new digital technologies. Studies in Philosophy and Education, 1-14.

López, N. M. M., Robles, A. C. G., Gómez, A. C. T., \& Hernández, J. A. (2017). Digital literacy to parents in the use of social networks. Alteridad: Revista de Educación, 12(1), 8-19.

Maden, S., Banaz, E., Maden, A. (2018). Türkçe öğretmeni adaylarının dijital ortamlardaki yazma alışkanlıkları. Ĕgitim ve Öğretim Araştırmaları Dergisi Journal of Research in Education and Teaching, 7 (1).

Maxwell, C. E., \& Maxwell, E. M. (2014). Gender differences in digital literacy among undergraduate students of faculty of education, Kogi State university: implications for eresources \& library use. Advances in Social Sciences Research Journal, 1(7), 96-108.

McDougall, J., Readman, M., \& Wilkinson, P. (2018). The uses of (digital) literacy. Learning, Media and Technology, 1-17.

Mikelic Preradovic, N., Lešin, G., \& Šagud, M. (2016). Investigating parents' attitudes towards digital technology use in early childhood: a case study from Croatia. Informatics in Education, 15(1), 127-146.

Murray, J. (2013). How to teach your students digital citizenship. Retrieved October 6, 2014 from:http://www.aplatformforgood.org/blog/entry/how-to-teach-yourstudents-Digital citizenship.

Ocak, G., \& Karakuş, G. (2018). Pre-Service teachers' digital literacy self-efficacy scale development. Kastamonu Education Journal, 26(5), 1427-1436.

Porat, E., Blau, I., \& Barak, A. (2018). Measuring digital literacies: Junior high-school students' perceived competencies versus actual performance. Computers \& Education, 126, 23-36.

Ragnedda, M., Muschert, G.W. (2013). The digital divide: the internet and social inequality in international perspective. New York: Routledge

Schartman, S. (2012). K-12 parents digital literacy survey. 28.09.2018 tarihinde https://www.researchgate.net/publication/313152281_adresinden alınmıştır.

Smith, B.N. \& Necessary, J.R. 1996. Assessing the computer literacy of undergraduate college students. Education, 117(2), 188-194.

Starr, L. (2012, March 31). Encouraging teacher technology use. Education World. 138 Retrieved from: http://www.educationworld.com/a_tech/tech159.shtml 
Svensson, M., \& Baelo, R. (2015). Teacher students' perceptions of their digital competence. Procedia-Social and Behavioral Sciences, 180, 1527-1534.

Techataweewan, W., \& Prasertsin, U. (2018). Development of digital literacy indicators for Thai undergraduate students using mixed method research. Kasetsart Journal of Social Sciences, 39(2), 215-221.

Tyger, R. L. (2011). Teacher candidates' digital literacy and their technology integration efficacy. (Unpublished Doctoral dissertation, Georgia Southern University). Retrieved from http://digitalcommons.georgiaso uthern.edu/cgi/viewcontent.cgi?article $=1557 \&$ context=etd.

Volman, M. (1997). Gender-related effects of computer and information literacy education. Journal of Curriculum Studies, 29(3), 315-328.

Zin, N. A. M., Zaman, H. B., Judi, H. M., Mukti, N. A., Amin, H. M., Sahran, S., ... \& Abdullah, Z. (2000). Gender differences in computer literacy level among undergraduate students in Universiti Kebangsaan Malaysia (UKM). The Electronic Journal of Information Systems in Developing Countries, 1(1), 1-8. 